\title{
Studies on feasibility of sustainable quality seed potato production technology and development of supply chain for the benefit of small and marginal potato growers of Karnataka
}

\author{
Shahid Ali*1 ${ }^{*}$ B.B. Kumar ${ }^{2}$, C.M. Kalleshwara Swamy ${ }^{2}$, M.S. Kadian ${ }^{1}$ and B.V. Ramakrishna ${ }^{1}$ \\ ${ }^{1}$ International Potato Centre (CIP-SWCA), New Delhi, India. \\ ${ }^{2}$ University of Agricultural and Horticultural Sciences, Shimoga, Karnataka, India. \\ *E-mail: s.ali@cgiar.org
}

\begin{abstract}
Management of aphid vectors in potato is important for the production of quality seed potato. Aphids are the major vectors of many potato viruses which transmit viral diseases limiting the seed potato production. To explore the area with aphid free/low population a weekly aphid observation was made in major potato growing areas of Chikkaballapur and Chickmagalur districts during rabiand kharif seasons to assess the build-up trends on the standing crop using aphid-leaf count and catches of yellow water pan and yellow sticky traps. Aphid population was below threshold level in the areas surveyed, however in Chickmagalur aphid build-up was erratic due to heavy rain fall followed by dry spells. Harvested potato in Chikkaballapur was treated and stored in cold storage for three months. During June, 50 per cent of the seed stock was transported to Chickmagalur area for planting in kharif season and remaining seed was used for planting in Chikkaballapur area during rabi season. In Chickmagalur, the harvested and treated seed was stored in low cost country potato store for three months and 50 per cent seed from warehouse was transported to Chikkaballapur for rabi planting and remaining seed was planted in Chickmagalur area during November thereby saving nearly 40 per cent of seed cost. Thus, the feasibility supply chain has been established making the local potato growers self-sustainable in quality seed potato production resulting in $30-40$ percent seed requirement met locally produced quality seed and non-traditional areas will be brought under potato cultivation. The breeder seed was multiplied under low cost insect proof net houses during rabi season in Chikkaballapur area, harvested seed was stored in cold storage thereafter distributed among the local potato growers for planting during kharif season in Chickmagalur area.
\end{abstract}

Key words: Management, aphids, sticky traps, water pan, abiotic.

\section{INTRODUCTION}

The Plateau area only accounts for $7 \%$ of the area and $4 \%$ of the production (Minhaset al, 2011).Karnataka is one of the important potato growing states in peninsular India. It is mainly cultivated in Kolar, Belgaum, Hassan, Chikkaballapur, Chickmagalur, Bangalore Rural and Dharwad districts. It is grown as rain-fed kharif crop in Belgaum, Chickmagalur, Dharwad and Hassan districts and as rabi crop in Chikkaballapur, Kolar and Bangalore Rural districts under protective irrigation. Unavailability of irrigation water for the rabi crop and repeated fall in kharif potato production due to heat and late blight stresses, however, limit the development of potato cultivation in this state (Rana et al, 2014).Potato is important cash crop in Karnataka produces 6,98,300 MT cultivated in an area of 44,400 ha with productivity of 15.72 tons per ha (Anonymous, 2013) and has a ready market within the state and neighbouring states.

The major limiting factor for low productivity in this area is non-availability of quality seed at affordable cost, presence of insect pests and diseases during the cropping season. Aphid vectors are transmitting the pathogenic viruses from infested to healthy crop limiting the disease-free seed potato production which further leads to fast degeneration (Aliet al, 2013; Sharmaet $a l, 2016$ ). 
Due to lack of trust of their on-farm grown potato can be utilised for seed purpose, Karnataka growers are dependent on the fresh seed material transported from distant North Indian plains undergoes serious quality deterioration when transported to Southern states, thus increasing the seed input cost (Rana et al, 2015).Augmentation of local seed potato production and supply is consequently the best way of increase in demand and reducing seed cost in the southern states. Hence, the study was undertaken for technical feasibility and economic viability of quality seed potato production and development of supply chain locally in the statemaking potato growers self-sustainable in seed potato production.

\section{MATERIAL AND METHODS}

Aphid monitoring studies have revealed that vector incidence and resulting virus pressure are much lower at higher elevations (Vucetic et al, 2013; Ali et $a l, 2015)$. To explore the area with aphid free/low population six plots of one hectare each were selected for weekly aphid count in Chikkaballapur and Chickmagalur districts during rabi and kharif seasons following 100 aphid-leaf count at random from top, middle and bottom of 33 plants and one bottom leaf from the $34^{\text {th }}$ plant making 100 leaves throughout the cropping period (Simpson, 1940). Beside aphid count on potato leaves, yellow sticky traps (YST) were mounted on posts $1.5 \mathrm{~m}$ from the ground coated with castor oil to capture alate aphids. Yellow water pan traps (YPT) filled with water mixed with light detergent powder were also installed in the selected plots at the crop level. The trapped a late aphids were removed weekly from the traps, counted, preserved in 70 per cent alcohol for identification up to species level.

Low cost semi-permanent double door insect proof net house was constructed during 2014 at Potato Research Station (PRS), Chikkaballapur in half an acre plot using PVC poles and 40 mesh nylon net. Three more low cost semi-permanent insect proof net houses measuring quarter an acre using granite poles and 40 mesh nylon net in farmers' fields were constructed during 2015 in Sadali, Chikkapylagurki and Chakuponahalli village of Chikkaballapur districts for multiplying breeder/quality seed potato under protected condition during rabi season.An innovative lowcostpotato storage structuresmeasuring $8 \times 8 \times 10$ and $10 \times 10 \times 10 \mathrm{ft}$ using areca nut logs with thatched roofing and racks are made with low cost areca nut wood planks. The structure has storage capacity of 2.5 and 4.0 tons, respectively were built in Kerkepete village and KVK, Mudigere in Chickmagalur district as a model during 2014 and 2016.The potato crop harvested during kharif 2014 was sorted/graded and treated with 3 per cent boric acid for 30 minutes to avoid bacterial wilt contamination and tubers were stored after shade drying covered with the chopped dried Lantana camara leaves to avoid the infestation of storage pests like potato tuber moth (Ali et al,2017).

\section{RESULTS AND DISCUSSION}

Aphid monitoring:

\section{Aphid incidence during rabi (average of three years) in Chikkaballapur area}

All the six locations monitored, aphid population was observed below the threshold level i.e. 20 aphids/ 100 compound leaves up to January but from the last week of January to first week of February aphid population was increased in all the locations due to increase in day temperature (Fig. 7). Aphis gossypii was found predominant in this location compared to Myzus persicae in the standing crop throughout the cropping period (Figure 1 to 6). A. fabae and A. spiraecola were also observed in the crop as well as in the aphid traps. 
Fig 1.

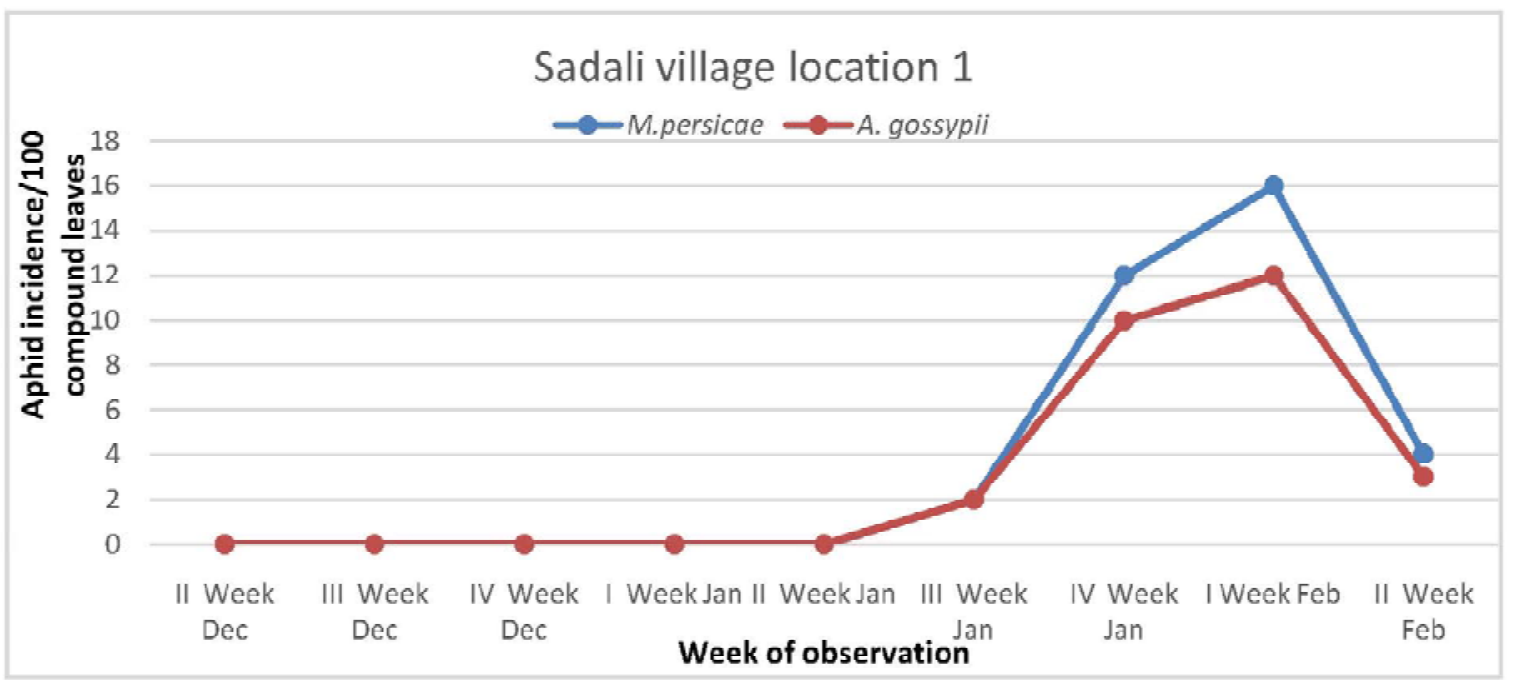

Fig 2 .

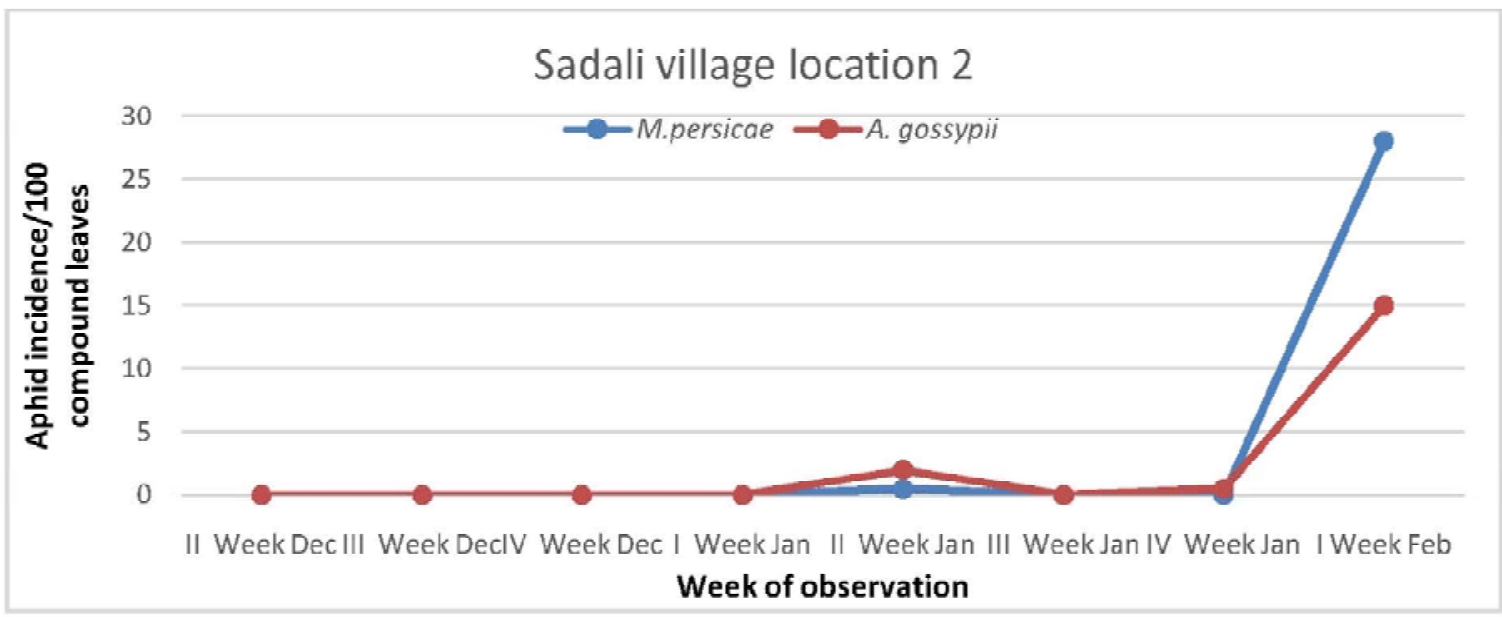

Fig 3.

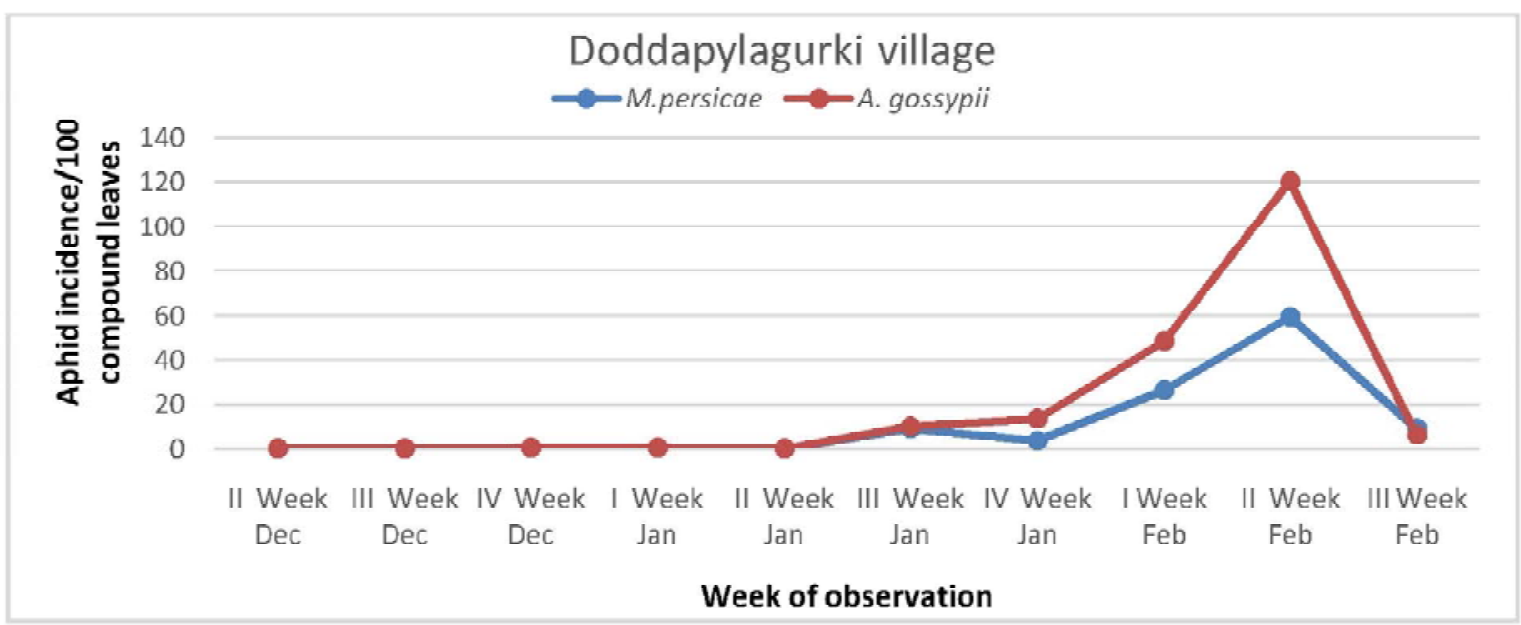


Fig 4.

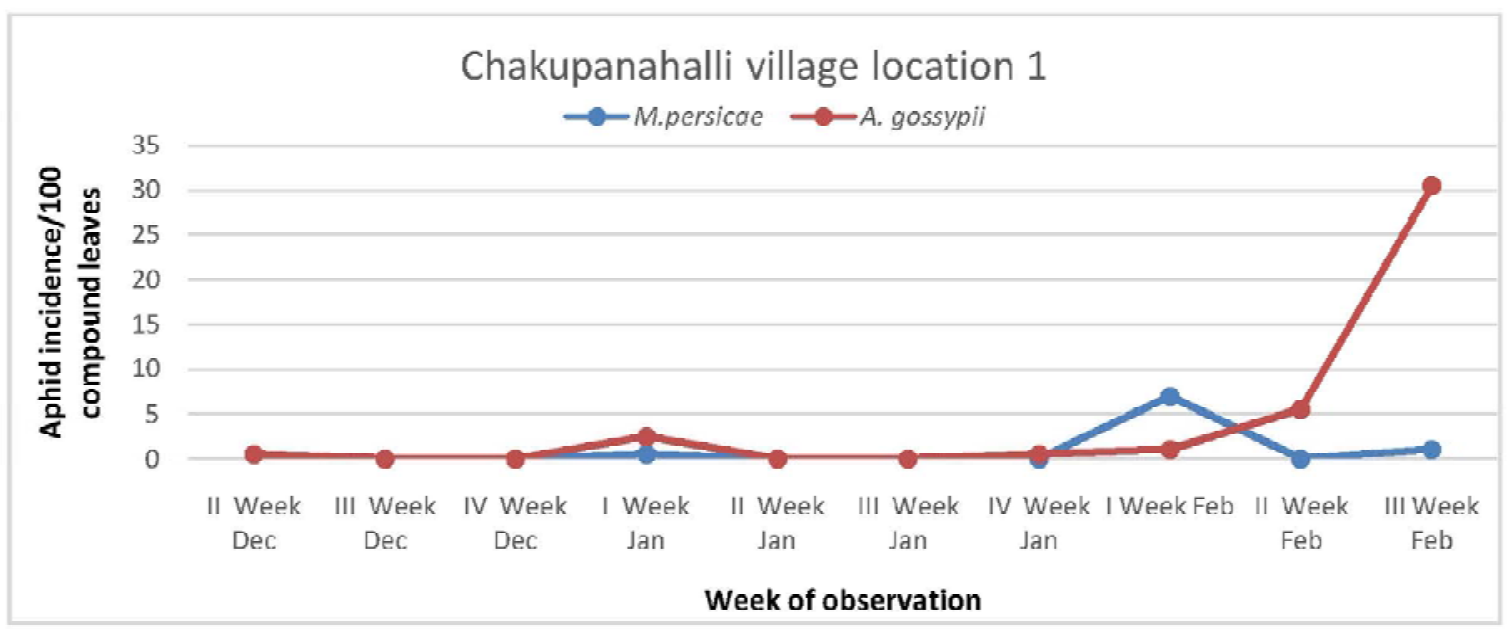

Fig 5.

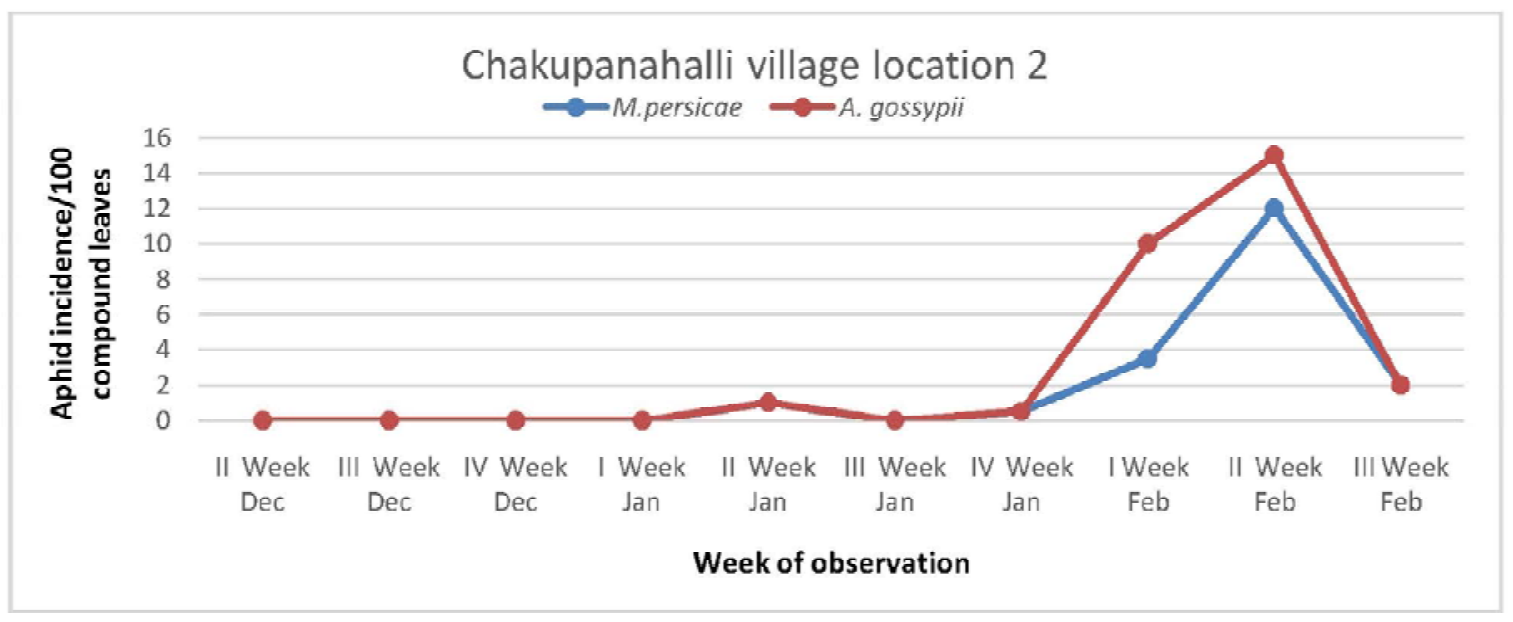

Fig 6.

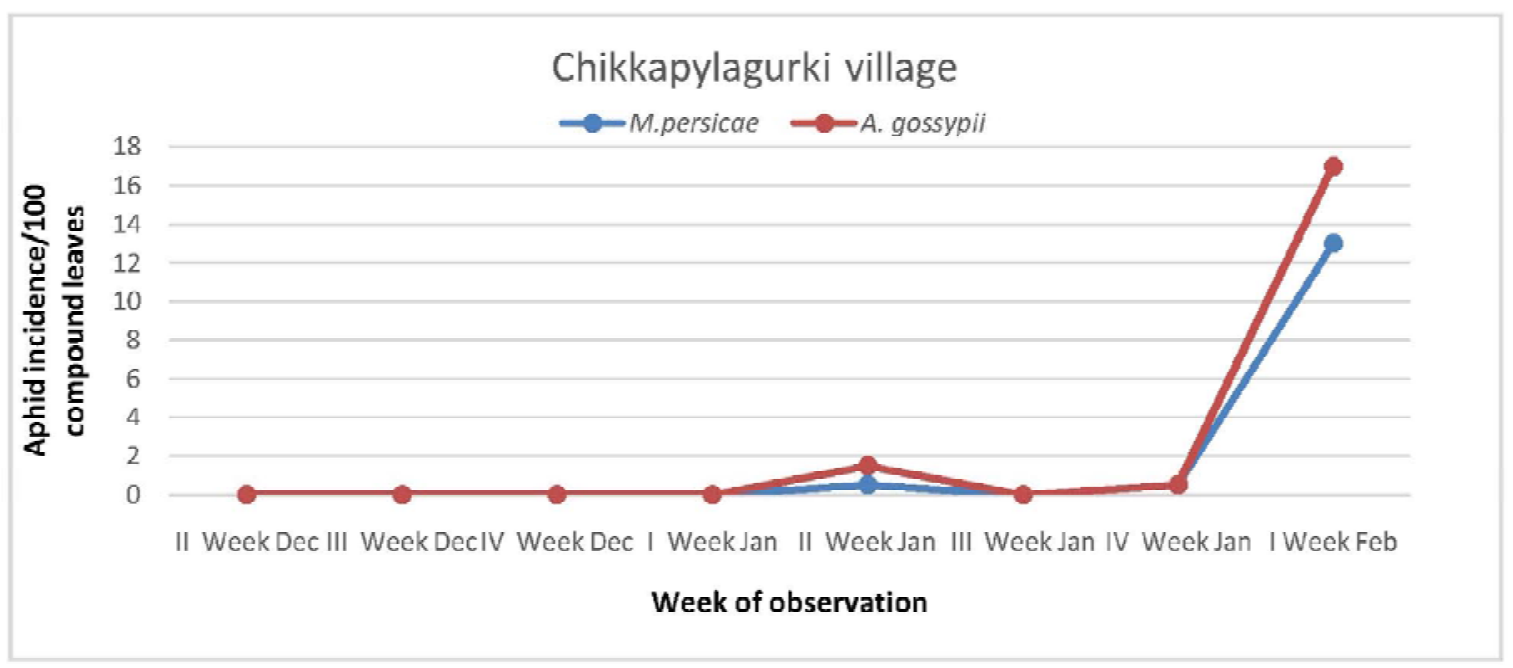


Fig 7.

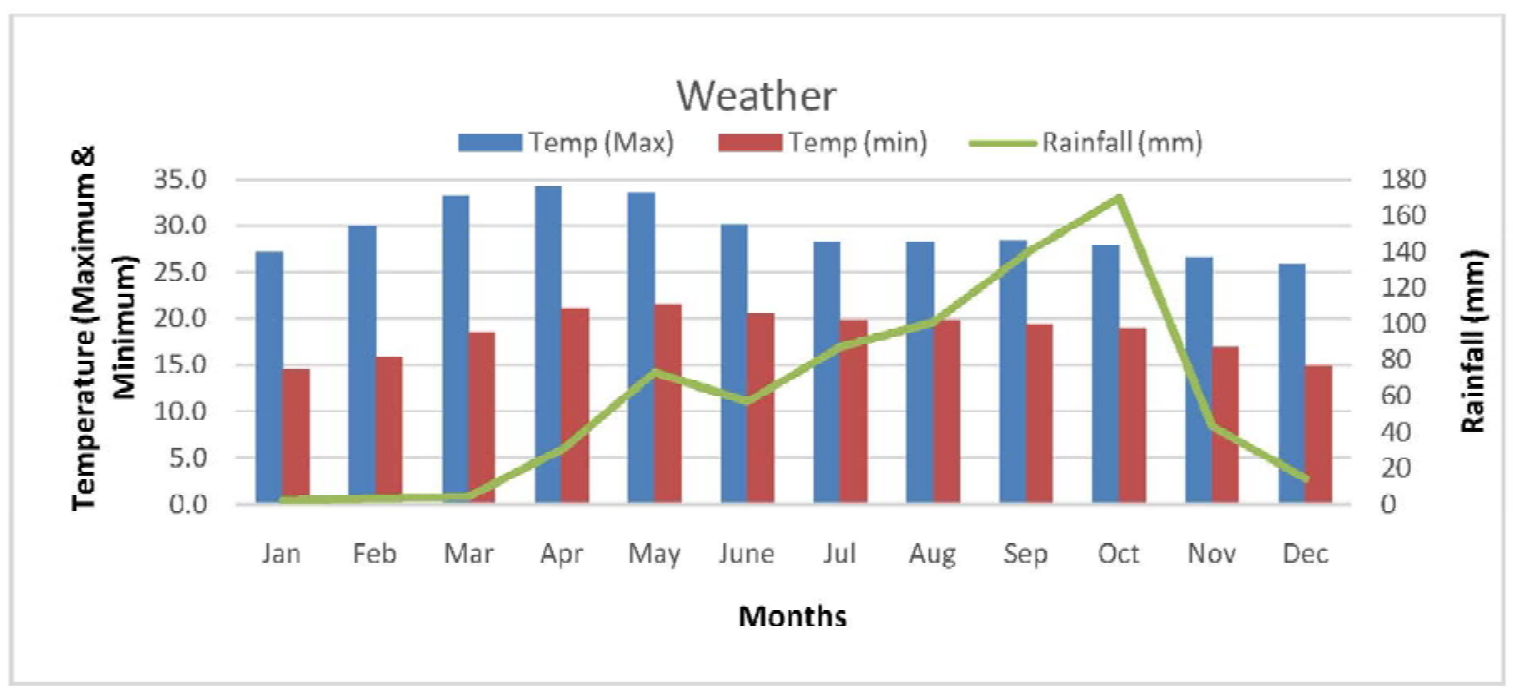

Aphid incidence during $k$ harif season (average of two years) in Tarikere Taluk of Chickmagalur District

The aphid build-up pattern was varied due to heavy rain followed by dry spells in this area during kharif season. Due to intermittent rainfall aphids are not able to colonize in the crop for a longer period. (Figure 8 to 13). M.persicae and A. gossypii are predominant species in this area. However, A. fabae, A. craccivora, Brevicoryn brassicae, Microsiphum spp. and A. spiraecola are also observed in the crop as well as in the aphid traps.
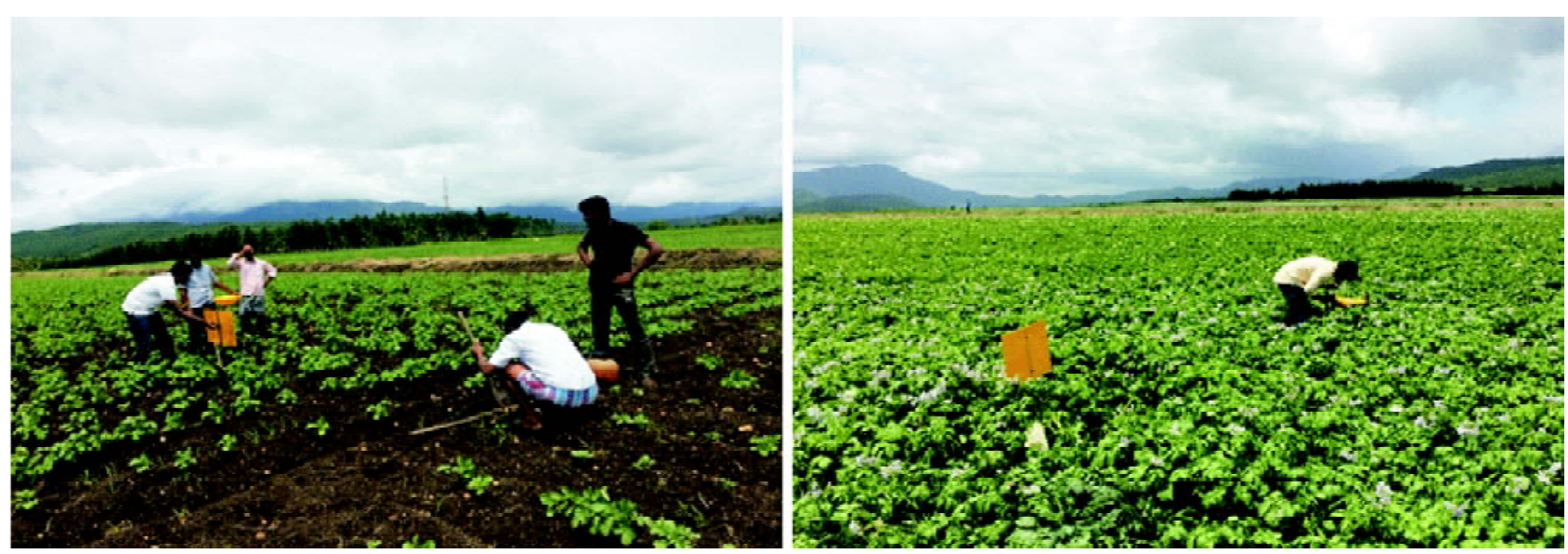

Installation for aphid traps into potato fieldCounting of aphids in the water pan trap 
Fig 8.

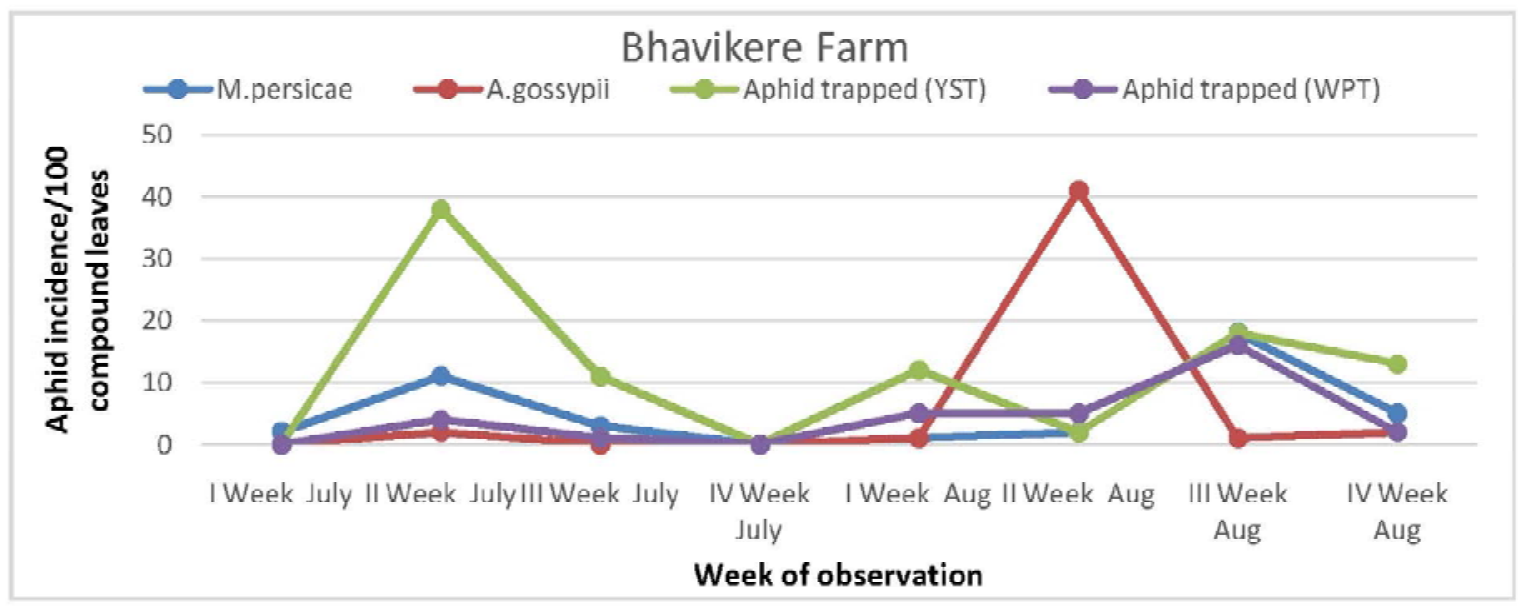

Fig 9.

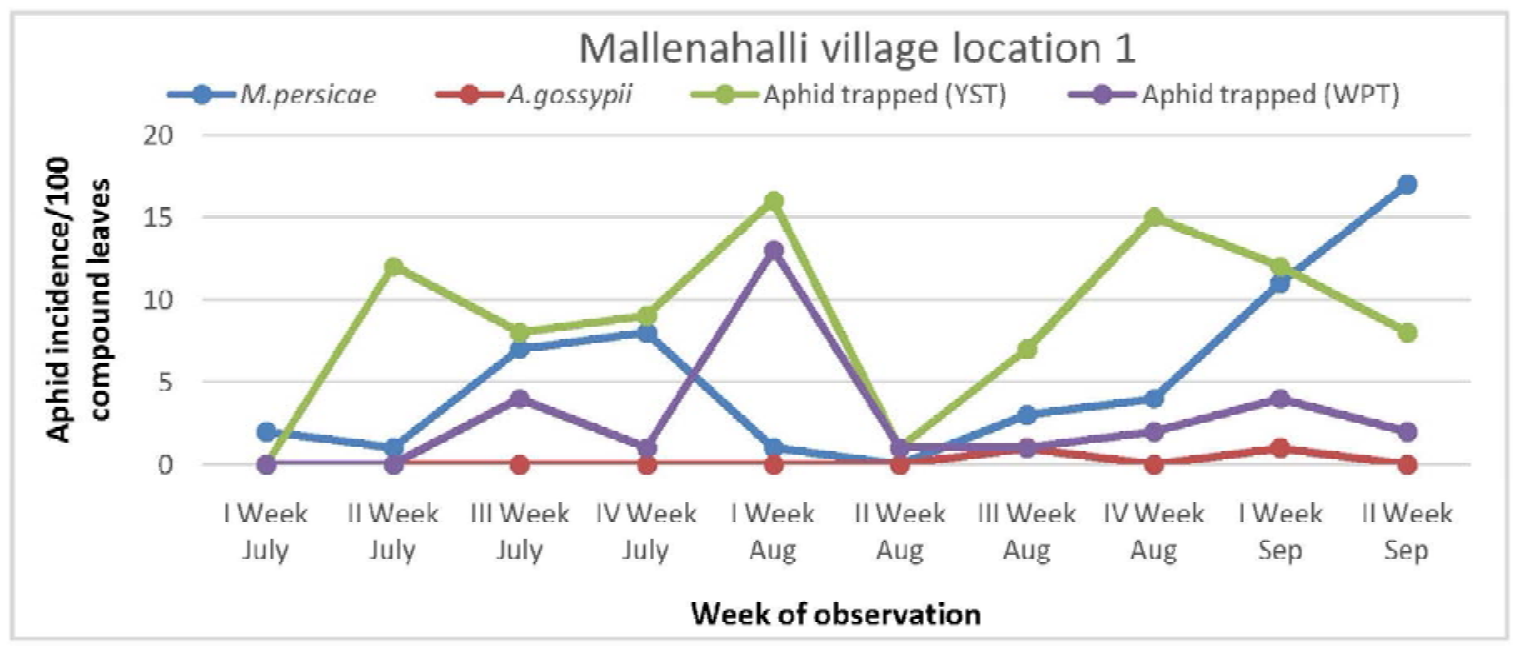

Fig 10.

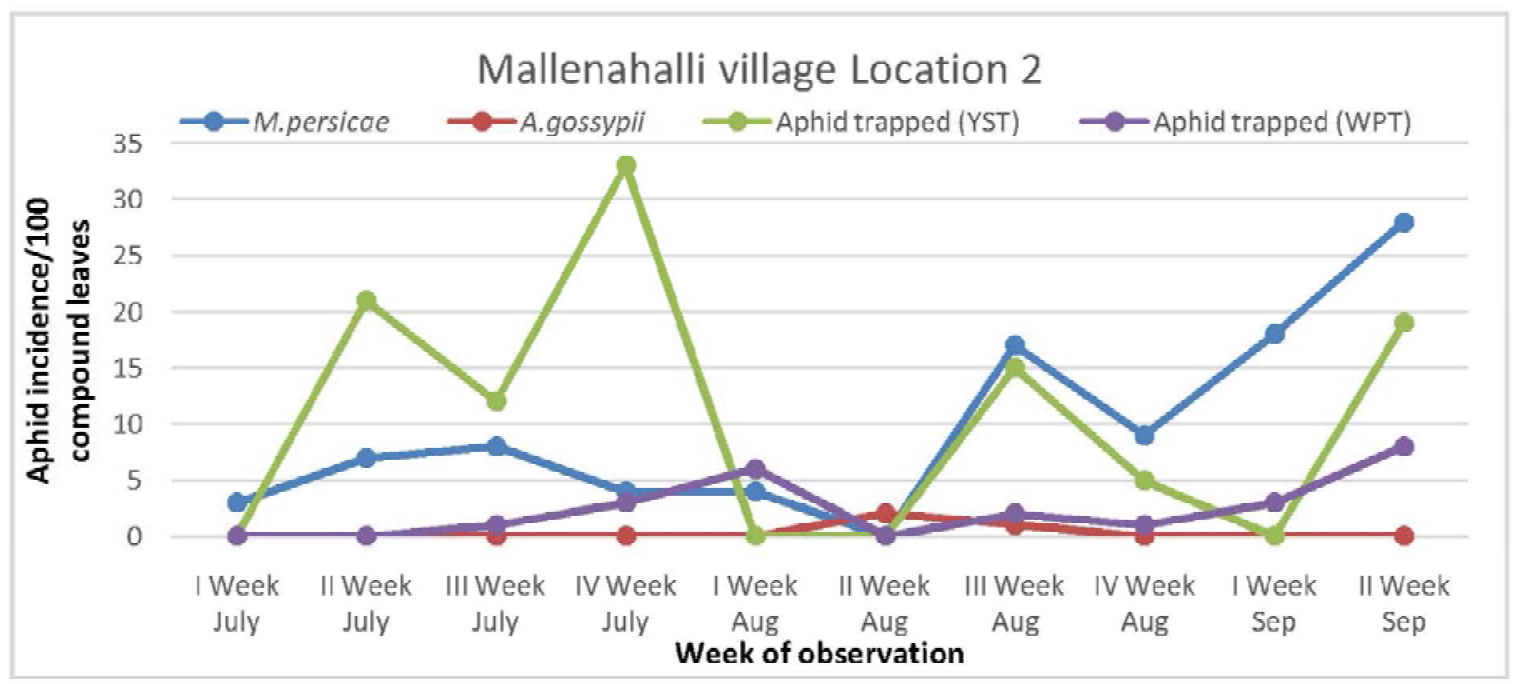


Fig 11.

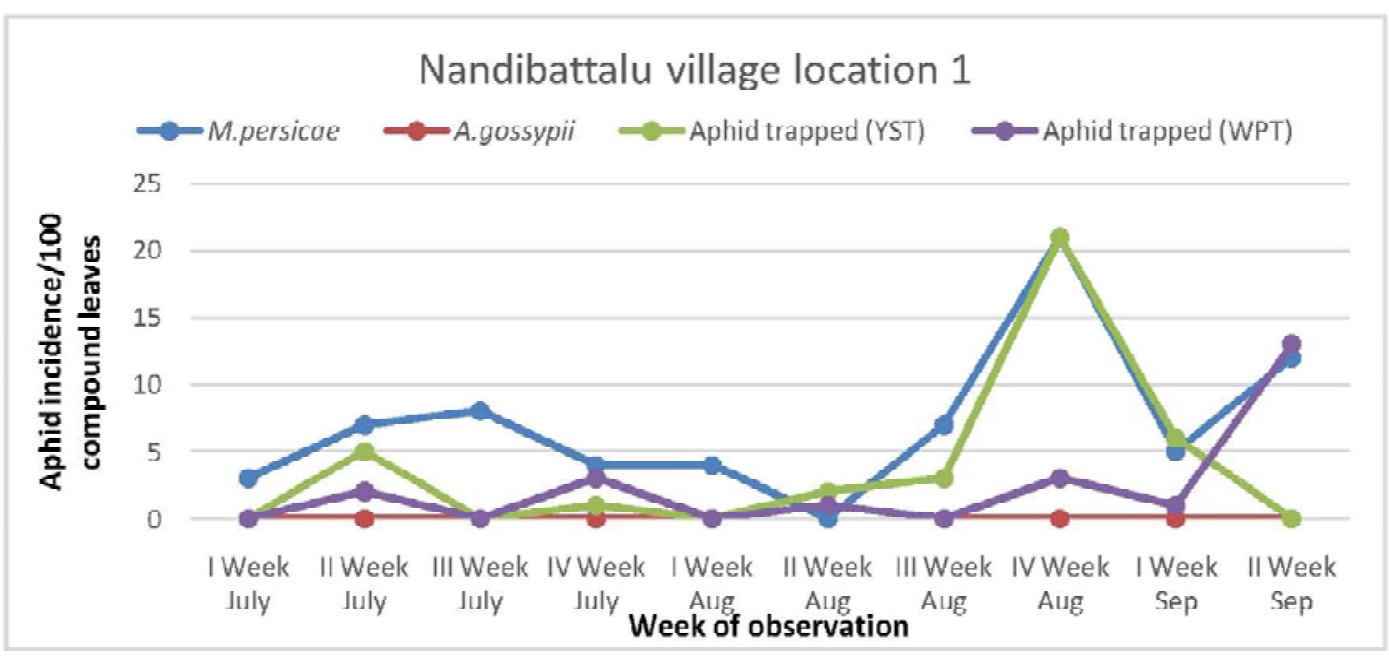

Fig 12.

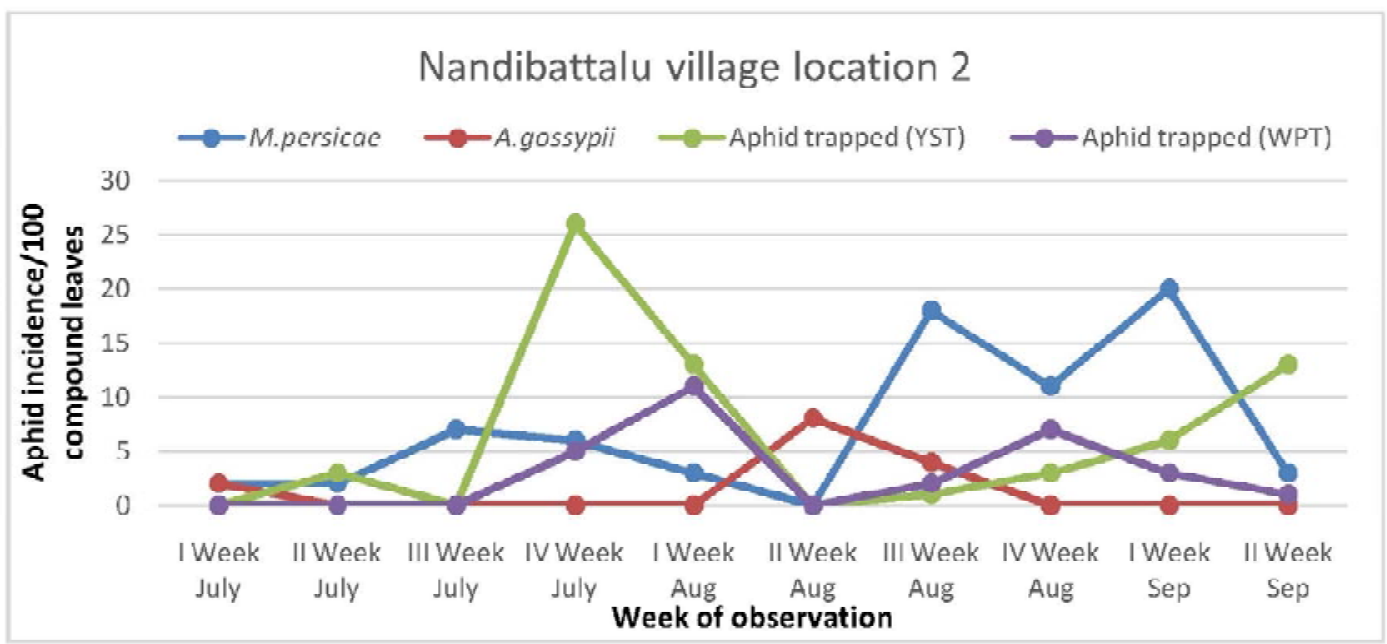

Fig 13.

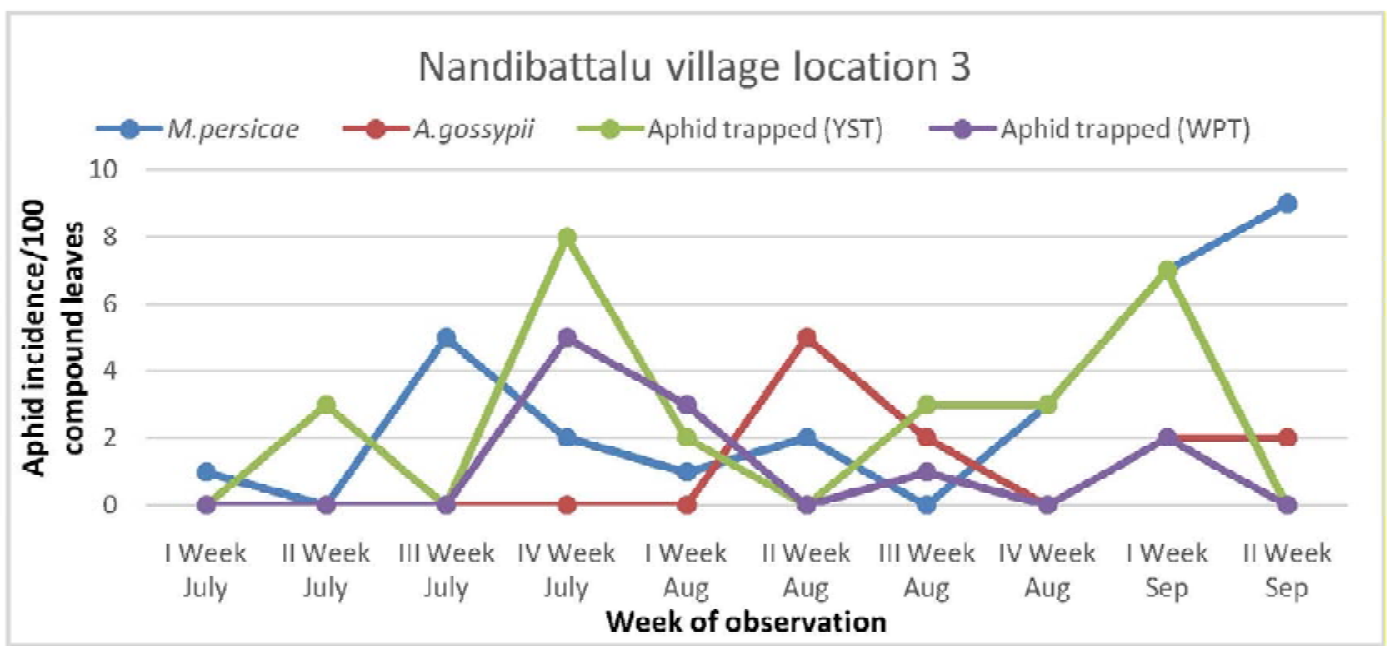




\section{Low cost wooden Country Potato Warehouse in Karnataka}

The harvested rabi crop in Chikkaballapur area was transported and stored in innovative warehouses in Chickmagalur for dormancy break (Ali et al, 2017)and the stored seed was utilised for planting in Chickmagalur area during kharif season. Harvested kharif potato in Chickmagalur was also stored in the warehouse for three months used in Chickmagalur and Chikkaballapur area during subsequent rabi season. By using this low-cost storage warehouse facility, small and marginal potato growers of Karnataka are able to retain good quality seed potato thereby saving nearly 40 per cent of potato seed cost.

\section{Development of seed potato supply chain for the benefit of small and marginal potato growers during kharif and rabi seasons in Karnataka}

The quality seed potato was planted in the month of November under the net house at PRS during two
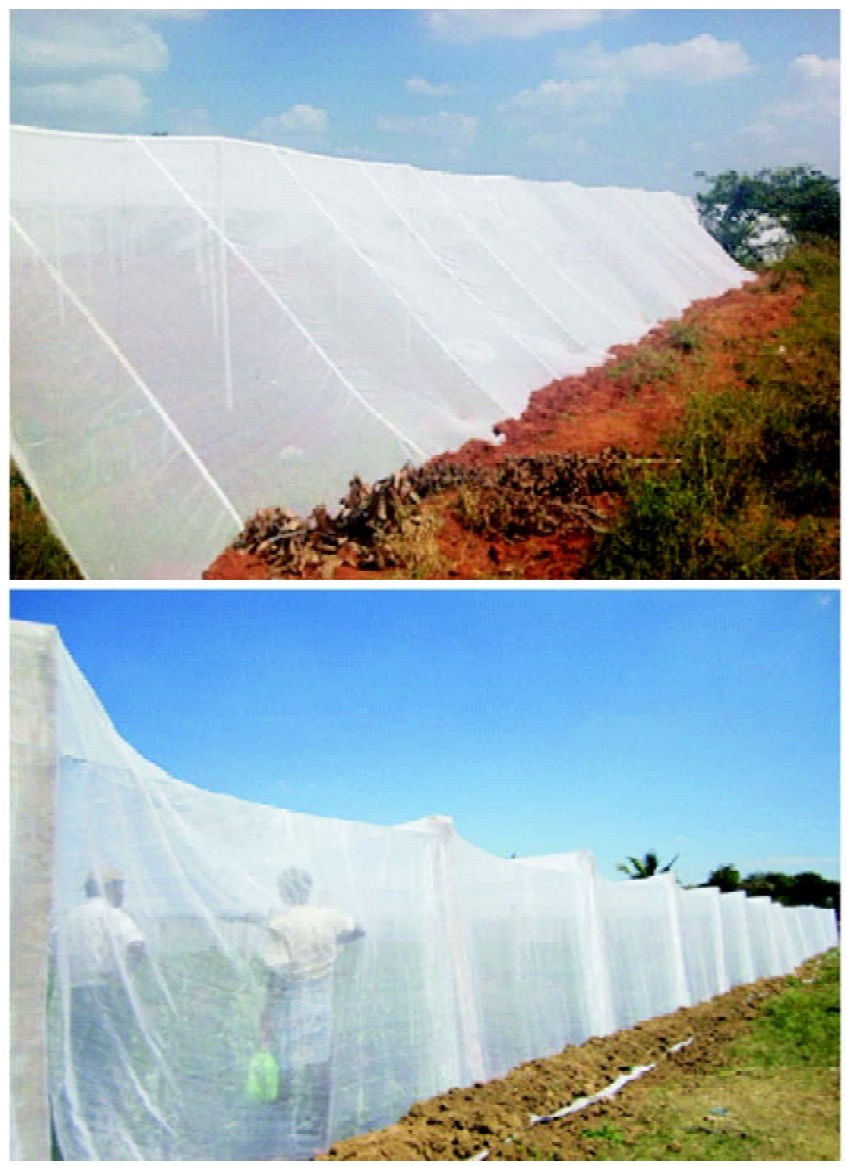

Low-cost insect proof net houses built by International Potato Center (CIP) in Chikkaballapur area

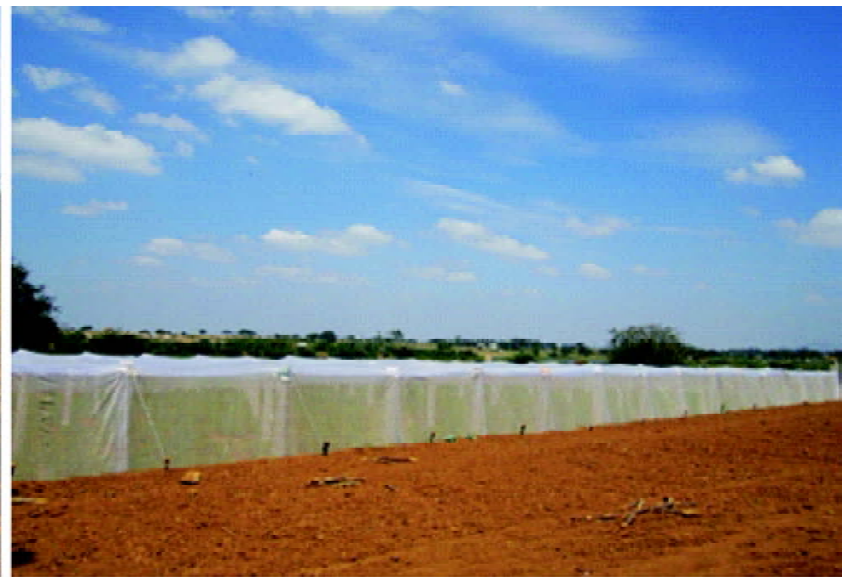

rabi seasons (2014-15 \& 2015-16) which were harvested during February, 2015 \& 16. Harvest was sorted/graded and treated by 3 per cent Boric acid for 20 minutes and shade dried. The seed was stored in the cold storage for three months. During June, 2015 and 2016, half of the stored seed stock was transported to Chickmagalur area for planting during kharif season and remaining seed was also used for planting in Chikkaballapur area during rabi season.

Likewise, the quality seed multiplied under protected insect proof nethouse condition at farmers' fields were harvested during the month of March, 2016 and graded/treated seed was stored in the cold storage for three months. During June, 2016 large and medium stored seed tubers were transported and planted in Chickmagalur area for kharif 2016 and remaining small tubers were retained in the cold storage up to August, 2016 for using the same seed stock during early rabi and rabi 2016 in Chikkaballapur area thereby saving nearly 40 per cent of seed cost (Annexure 1).

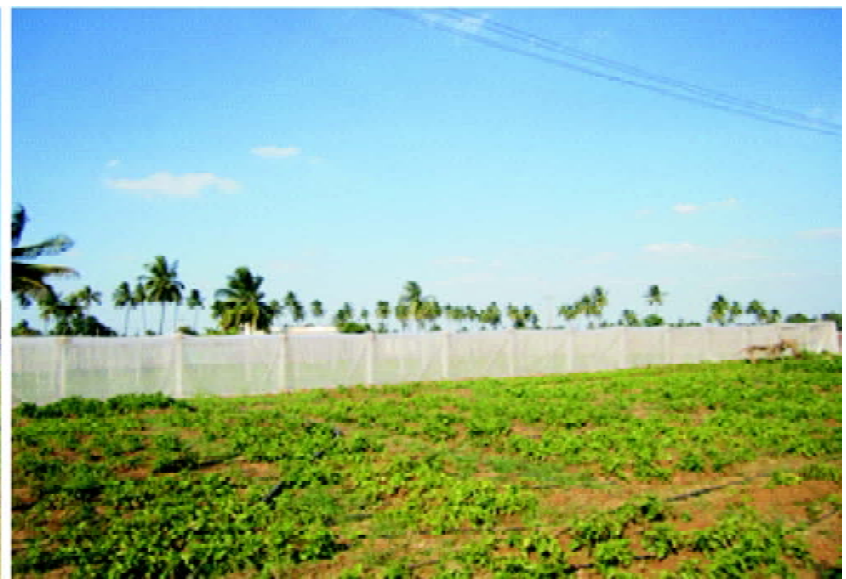


Annexure 1. Seed potato production and development of seed potato supply chain for the benefit of small and marginal potato growers during kharif and rabi seasons in Karnataka

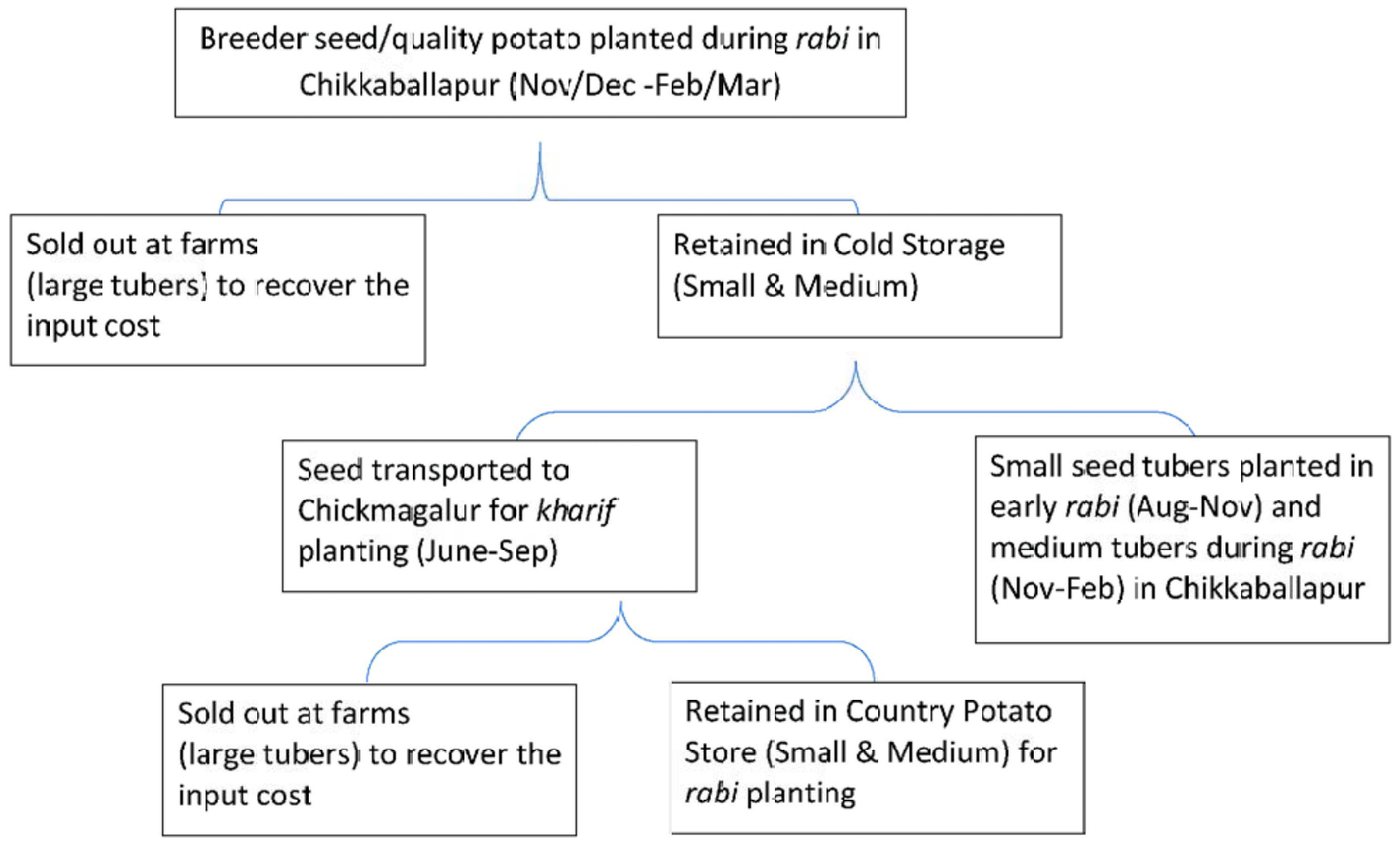

\section{ACKNOWLEDGEMENT}

The authors acknowledge Indian Council of Agricultural Research (ICAR) for funding grant to accomplish the research work for benefit of small and marginal potato growers of Plateau region of Karnataka state, India. The authors appreciate comments from Dr. Kalleshwara Swamy, CM, and BV Ramakrishna and overall review by MS Kadian.

\section{REFERENCES}

Anonymous 2013. Database on potato Statistics, Central Potato Research Institute, Shimla, H.P; India (http://14.139.61.86/st_arprodyld/ default.aspx).

Ali, S., Kadian, M.S., Ortiz, O., Singh, B.P,Chandla, V.K.and Akhtar, M.2013. Degeneration of potato seed in Meghalaya and Nagaland states in North Eastern Hills of India. Potato J.40(2):122-127

Ali, S., Kadian, M.S., Akhtar, M., Arya, S., Chandla, V.K., Govindakrishnan, P. and Singh, B.P. 2015. Potato Virus-Vector Aphid Epidemiology in North-Eastern Hillsof India. Natl. Acad. Sci. Lett.38 (2): 139-42
Ali, S., Kumar, B.B., Kalleshwaraswamy, C.M., Kadian, M.S., Ramakrishna, B.V. and Singh, B. 2017. Low cost potato warehouse facility for Karnataka: A success story. J.Hortl. Sci. 12(1): 85-87

Minhas, J.S., Rawat, S.,Govindakrishnan, P.M. and Kumar, D.2011. Possibilities of enhancing potato production in non-traditional areas. Potato J.38(1): $14-17$

Rana, R.K., Kadian, M.S., Ali, S., Arya, S., Singh, B.P., Swamy, K.C.M., Kumara, B.B.and Ramakrishana, B.V.2014. Baseline indicatorsdeveloping farmer based potato system in nontraditional seed producing areas to benefit 
farmers of plateau region Karnataka of India. CIP SWCA-NASC Complex, New Delhi, 34 p.

Rana, R.K., Arya, S., Kumar, S., Singh, B.P., Adinarayana, G., Kumar, S., Quiroz, R.., Kadian, M.S. 2015. Benchmarking farmers' economic and social status in Anantapuramu and Kurnool arid districts of Andhra Pradesh for probable introduction of potato crop. Economic Affairs. (India). 60(4):699-706

Sharma, S.T., Abdurahman, A., Ali, S., AndradePiedra, J.L., Bao, S., Charkowski, A.O., Crook, D., Kadian, M., Kromann, P., Struik, P.C.,
Torrance, L., Garrett, K.A. and Forbes, G.A.2016.Seed degeneration in potato: the need for an integrated seed health strategy to mitigate the problem in developing countries. Plant Pathology, 65, 3:16

Simpson, S.W. (1940) Aphid and their relation to the field transmission of potato virus diseases in North East Maine. Maine agricultural experiment station. Bulletin 40:3

Vucetic, A., Jovicic, I., Petrovic-Obradovic, O. 2013. The pressure of aphids (Aphididae, Hemiptera), vectors of potato $\mathrm{v}$ Aliiruses. Archives of Biological Sciences65, 659-66

(MS Received 18 January 2018, Revised 29 May 2018, Accepted 30 June 2018) 